\title{
Knowledge, attitudes and perceptions of stakeholders on biofuels as an enabler in a South African bio-based economy
}

\author{
Chipo Mukonza* \\ Institute of Corporate Citizenship, University of South Africa, P O Box 392, Unisa 0003, South Africa
}

\begin{abstract}
This study investigates stakeholder knowledge, attitudes, and public perception concerning biofuels as an enabler towards a bio-based economy. In innovation and adoption studies, perceptions play a critical role in the acceptance of a technology. Biofuels have been touted as a clean fuel with an ability to reduce greenhouse gas emissions while simultaneously creating employment and growing economies. South Africa is in the process of transitioning towards a bio-based economy. Accordingly, policies and institutions have been developed to promote biofuels production and distribution. Knowledge, attitude and perception (KAP) surveys were carried out to deepen knowledge and understanding of the stakeholder's KAP. Emails as well as telephonic and group interviews based on open questions and social
\end{abstract}

media were used to gather data. The study employed cluster, purposive random and snowball sampling to select the participants with descriptive statistics, thematic analysis and discourse analysis used to analyse the data. The study found that the introduction of biofuels presents many opportunities and benefits for the economy and unlocking the potentials for rural entrepreneurs. Stakeholders have concerns and issues regarding the use of biofuels on their internal combustion engines. The study recommends proper communication and education should be done on the benefits of biofuels in a bio-based economy.

Keywords: biofuels; energy; public acceptance; South Africa. 


\section{Introduction}

Energy efficiency, renewable energy promotion as well as reduction of greenhouse gases (GHGs) are goals that countries must pursue, under their obligations in the frameworks of the Kyoto Protocol and other binding commitments (Brent, 2014). An increasing number of policies, programes, and projects have been put in place to support the use of biofuels by both developed and developing countries since 2008. Incentives such as mandatory blending targets and tax advantages, as well as research and deployment strategies for advanced biofuel technologies, have been set up to enhance energy security (Pradhan and Mbohwa, 2014). These measures were taken following high energy prices, augmented by concerns about the energy security and environmental consequences of GHG emissions. The world is still, however, failing to transition from the current global energy system to a more sustainable model, despite the use of these incentives (Bioethanol for Sustainable Transport, 2009; International Energy Agency (IEA), 2013; Wesseler and Zilberman, 2016).

Biofuels can be defined as all energy sources derived from biomass. Liquid biofuels are particularly considered for use in transportation and can be divided into several types and sub-types, according to kind, as well as to the technologies used for production (Jumbe et al., 2009). Biofuels for transportation comprise both bioethanols made from sugar components of plant material as a substitute for gasoline, and biodiesel made from plant oils or animal fats as a replacement for fossil diesel (Jensen et al., 2013). Biofuels have also been promoted as a solution to growing concerns about increasing reliance on foreign oil. Recent studies have concluded that biofuels can help solve the energy crisis, especially as more advanced technologies are made available (Amigun et al., 2011). Rapid developments, increased production and use of biofuels were reported in the last decade (Funke, 2010).

There is, however, inadequate research regarding knowledge, attitudes and perceptions of stakeholders. In South Africa, the National Development Plan (NDP), which was released by the National Planning Commission with a vision for 2030 (NPC, 2011), emphasised the need for South Africa to move away from the unsustainable use of natural resources and transition to a resilient, low-carbon economy. The NDP, to this end, includes proposals to support a carbon-budgeting approach, linking social and economic considerations to carbon emission-reduction targets. Against this background, the present study seeks to understand the knowledge attitudes and perceptions of biofuels stakeholders in South Africa that contribute to the growing literature on biofuels and their public acceptance. Early sections include background, a literature review, and a discussion of methodology; these are followed by sections presenting results and discussion and, finally, conclusions and recommendations.

\section{What is a bio-based economy?}

A bio-based economy is one whose public goods are based on production paradigms that rely on biological processes. Bio-economy actions consists of natural ecosystems, natural inputs, and expansion of minimum amounts of energy that do not produce waste as all materials discarded by one process and are reused in the ecosystem (Upham et al., 2009). The bio-based economy uses first-generation biomass (crops), second-generation biomass (crop refuse) and third-generation biomass (seaweed, algae). A bio-based economy is more than a collection of technical development, however. It includes paradigm change, causing creative destruction as it introduces innovations. These innovations normally set off a series of changes where existing systems should be adjusted. When introducing biofuels (and other elements of bio-based economy), the rationale is that they reduce consumption of fossil fuels and dependence on fossil fuel exports, thus also reducing GHG emissions. The impact of the changes that might be needed can be significant. The introduction of biofuels and other elements of the bio-based economy are neither an isolated development nor unique in history (Upham et al., 2009).

It is imperative to have well-functioning biorefinery chains when transitioning to a bio-based economy. There are both benefits and risks in introducing biofuels. The benefits include sustainable reduction of carbon dioxide emissions, building competitive bio-industries, and new business opportunities. The risks include collisions between food-production, agriculture and the environment especially when policies are developed and implemented in a disintegrated way. Moreover, accompanying the introduction of biofuels include competition between food supply and biomass production and consumers (IEA, 2013; Amigun et al., 2011). Given the issues that are associated with biofuels in a bio-based economy, it is necessary to look at the concept of sustainable development, which emerged as a logical extension of arguments developed in the environmental literature of the 1960s, 1970s and early 1980s, responding to the growing environmental concerns resulting from human development activities that were reaching global proportions (Nhamo et al., 2011). The view of Oltra (2011) was that an integrated approach is needed to evaluate the impact of the bio- based transition touching all dimensions of sustainability and simultaneously integrating the related innovations. The sustainability focus has been chosen because of the similarities between policies aiming at enhancing the bio-based 
transition and other sustainability policies. Exploitation of biofuels has a great influence on the technical, economic and lifestyle elements of a society. It is crucial to consider not only the technical innovations required to transition to a bio-based economy, but also to examine the conditions of biofuel production, the processes, markets, policy and other social structures. It is these conditions that will determine how biofuels will be implemented, and account for the reactions of producers, researchers, consumers, and non-governmental organisations (Prokop et al., 2007). Examining social structures enables the gauging of people's knowledge, attitude and perceptions regarding biofuels as an enabler in a bio-based economy. Knowledge can be defined as a construct formed by interlinking numerous psychological components comprising of various theories and hypotheses (Prokop et al., 2007). Environmental knowledge can be regarded as synonymous with scientific literacy (Prokop et al., 2007; Oltra, 2011). Attitudes are a collection of beliefs and often linked to emotional reactions and willingness to do something. Perceptions describe the initial responses to phenomena more than conceptions. Perceptions, along with attitudes, are crucial components of learning and have a causal relationship with it (Hader et al., 2010). The study of relations between knowledge, perceptions and attitudes are among the most examined topics in psychology (Brown et al., 2010).

Figure 1 is a schematic presentation of why biofuels have been advocated in a bio-based economy.

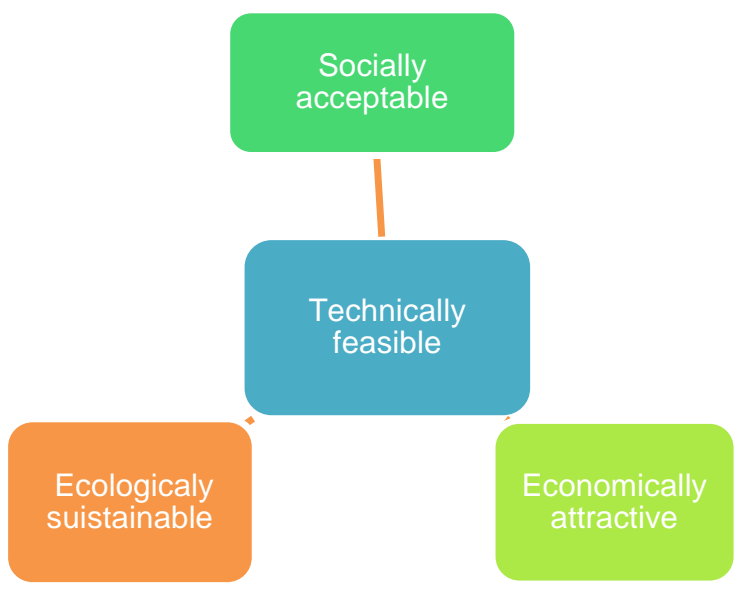

\section{Figure 1: Biofuels in a bio-based economy.}

Benefits of bio-based economy cover all the dimensions of sustainable development that are economical, environmental and social. Wesseler and Zilberman (2015) provided six reasons why the bio-economy was a sector of growing importance: (1) the recent advances in biological sciences; (2) the increase in horizontal and vertical integration in agricultural supply chains; (3) the increase in inter- and intra-industry trade; (4) the advance in information; (5) the increase in globalisation; and (6) the challenges caused by climate change. Now more than ever the growing integration between different sectors means that there is need to broaden the range of concerns of the different players in the economy (Clever Consult BVBA, 2010). This will affect their strategic interactions, attitudes towards policies, and efforts to affect policy formations affecting the bioeconomy. Michael et al. (2012) contended that an understanding of how the public evaluates risks and benefits for emerging innovations such as biofuels is crucial for policy-makers and industry leaders alike to determine the future of scientific energy innovation. More importantly, carrying out such as study like this could open a dialogue between the public and those in the scientific community by suggesting strategies for effective communication.

\section{Development of biofuels in South Africa}

South Africa has proposed biofuels as part of its energy mix (White paper on renewable energy, 2003; Biofuels Industrial Strategy, 2007), with several push and pull factors considered. Some of the drivers include:

- limited oil reserves and imports a significant amount of oil to meat nations requirement;

- saving on the heavy foreign exchange import bill;

- reducing the carbon footprint (South Africa is among the top 20 countries in terms of GHG emissions);

- increase local energy access;

- improving the agricultural sector and its market; and

- economic development and job creation.

Several policies and institutions were established to support biofuel production and use. Government proposed to achieve its ends by regulating the geographical location of biofuel production plants and commodities that may be used to produce biofuels (DME, 2007). Biofuel strategy (2007) stipulates a blending rate of $2 \%$, which is a significant change from the $4.5 \%$ proposed in the White paper on renewable energy of (2003). The rationale of a $2 \%$ blending rate is that it will not impact the country's overall food security negatively (DME, 2007). Biofuels Strategy (2007) proposed that crops will be used as feedstock for bioethanol production using sugar-based commodities. Crops that are going to be used include sugarcane, sugar beet, sunflower, canola for bioethanol soybeans for biodiesel production. Policies and strategies that have been put in place supporting biofuels in bio-based economy include those in Table 1. 
Table 1. Policies and strategies supporting biofuels in South Africa

\begin{tabular}{|c|c|}
\hline Policy & Comment \\
\hline $\begin{array}{l}2003 \text { White paper on renewable energy (Depart- } \\
\text { ment of Minerals Energy, DME, 2003) }\end{array}$ & $\begin{array}{l}\text { Sets a renewable-energy target of } 10000 \text { GWh (equivalent to } \\
0.8 \text { Mtoe) to be achieved by } 2013 \text {. }\end{array}$ \\
\hline $\begin{array}{l}2005 \text { Renewable Energy Capital Subsidy } \\
\text { Scheme administered by the DME }\end{array}$ & $\begin{array}{l}\text { In } 2006 / 7 \text {. The subsidy provides for } 16.7 \mathrm{c} / \mathrm{l} \text { subsidy for bio- } \\
\text { ethanol and } 27.3 \mathrm{c} / \mathrm{l} \text { for biodiesel, up to a maximum of } \mathrm{R} 20 \\
\text { million. }\end{array}$ \\
\hline $\begin{array}{l}2007 \text { National Biofuels Industrial Strategy: } 2 \% \\
\text { biofuels penetration to the current fuel by } 2013 \text {; } \\
\text { Biofuels Industrial Strategy of the Republic of } \\
\text { South Africa ( DME, 2007) }\end{array}$ & $\begin{array}{l}2 \% \text { biofuels penetration that will have a producer support } \\
\text { scheme requires the use of local crops grown mainly on cur- } \\
\text { rently underutilised land in the former homelands and support } \\
\text { from the commercial land. }\end{array}$ \\
\hline $\begin{array}{l}2008 \text { National Energy Act }(34 / 208) \\
\text { Department of Energy } 2008\end{array}$ & $\begin{array}{l}\text { The Act was established to diversify energy resources ensuring } \\
\text { that the prices are affordable to ordinary people on the } \\
\text { ground and being produced in a sustainable manner. }\end{array}$ \\
\hline Green Economy Accord 2009 & $\begin{array}{l}\text { Government through the accord commits to procure } 3,725 \\
\text { MW of RE for the national grid by } 2016 \text { and to create at least } \\
50,000 \text { green jobs by } 2020 \text {. }\end{array}$ \\
\hline 2011 National Development Plan & $\begin{array}{l}\text { The vision of the document is to see the South African energy } \\
\text { market diversified through the use of IPPs. The paper envi- } \\
\text { sions South Africa increasing generation electricity reserves } \\
\text { from } 1 \% \text { in } 2014 \text { to } 19 \% \text { in } 2019 \text { which will require the devel- } \\
\text { opment of } 10 G W \text { of additional electricity capacity by } 2019 \\
\text { against the baseline of } 44 G W .10 G W \text { of this is to be sourced } \\
\text { from renewable sources such as the solar and wind. }\end{array}$ \\
\hline $\begin{array}{l}2012 \text { regulations regarding mandatory blending } \\
\text { of biofuels with petrol and diesel (promulgated } \\
\text { under government Notice R671 of } 23 \text { August } \\
\text { 2012; Department of Energy ( } 23 \text { August 2012) }\end{array}$ & Regulates the mandatory blending of petroleum products. \\
\hline $\begin{array}{l}2012 \text { Government Gazette 23/08/2012. } \\
\text { No35023(R671 Petroleum Products Act } \\
\text { (120/1977); }\end{array}$ & \\
\hline $\begin{array}{l}2012 \text { Regulations regarding the mandatory } \\
\text { blending of biofuels with petrol and diesel } 671 \text { of } \\
23 / 08 / 2012 \\
\text { Department of Energy. Government Gazette. Re- } \\
\text { public of South Africa no 36890(30 September } \\
\text { 2013) }\end{array}$ & $\begin{array}{l}\text { It was proposed that } 1 \text { October } 2015 \text { would be the date when } \\
\text { mandatory blending would come into operation. By end of } \\
2016 \text { it had not come into effect. }\end{array}$ \\
\hline $\begin{array}{l}\text { The Bio-economy Strategy } 2013 \text { (Department of } \\
\text { Science and Technology) }\end{array}$ & $\begin{array}{l}\text { The strategy provides an economic engine that will in turn } \\
\text { provide a basis for future growth. Bio-economy in the South } \\
\text { African context encompasses technological and non-techno- } \\
\text { logical exploitation of natural resources such as animals, plant } \\
\text { biodiversity }\end{array}$ \\
\hline $\begin{array}{l}2014 \text { draft position paper on the South African } \\
\text { biofuels regulatory framework. Notice } 24 \text { of } \\
\text { 2014. Government Gazette No37232 (Notice } 24 \\
\text { of } 2014 \text { ( } 15 \text { January 2014) }\end{array}$ & $\begin{array}{l}\text { Provided the implementation plan of mandatory blending in } \\
\text { South Africa. The set criteria for eligibility of manufactures for } \\
\text { governments support were premised on the fact that the indi- } \\
\text { vidual projects should benefit the country's macro-economic } \\
\text { objectives. }\end{array}$ \\
\hline
\end{tabular}




\section{Knowledge, attitude and perceptions on biofuel production}

The focus of the present research was to investigate knowledge on attitudes and perceptions of stakeholders regarding biofuel in a bio-based economy. There are, in fact, numerous stakeholder groups holding differing perceptions and opinions about bioenergy and its benefits (Dwivedi and Alavalapati, 2009). This complexity makes public understanding and support for bioenergy essential elements of policies aimed at the introduction and wider use of bioenergy (Rohracher et al., 2004). Clarkson (1995) defined stakeholders more narrowly as risk-bearers, arguing that a stakeholder has some form of capital at risk (either financial or human), and therefore has something to lose or gain, depending on a company's behaviour. The stakeholder concept has been widely used, and in this investigation is defined, according to the definition of Freeman (1984), as any group or individual who can affect or is affected by the achievement of the relevant objectives.

Several studies have been carried out (including Morone et al., 2009; Jensen et al., 2011) to assess public acceptance, biofuels producers' opinions and challenges, as well as youth knowledge regarding biofuels. Halder et al. (2010) investigated knowledge and perceptions of bio-energy among pupils in North Karelia, Finland. Data was drawn from 495 grade nine students who mostly revealed a lack of in-depth knowledge about different renewable energy sources, including bioenergy. Only a small percentage had a 'high' level of knowledge about bioenergy, while the majority indicated critical perceptions of it. Statistically significant gender differences were not apparent, though girls appeared to be more knowledgeable than boys. Results also showed a clear urban and rural difference in perceptions of bioenergy, with urban respondents more positive than their rural counterparts. A further study investigated knowledge, perceptions and attitudes to bio-energy among 1903 students in Finland, Slovakia, Taiwan and Turkey. The study established statistically significant relationships involving gender and locality on students' perceptions Halder et al., 2012). In Denmark, a survey was made of 274 fleet operators that already had some ethanol flex fuel vehicles in their fleet. The survey showed that participating organisations were initially influenced by environmental considerations and issues like the green image and corporate social responsibility when purchasing their first ethanol vehicles. Their overall experience with ethanol vehicles was positive, despite concerns about fuel cost, refuelling infrastructure, driving range, and capital/operating costs (Bioethanol for sustainable transport, 2009).

Other studies have investigated recent changes in media framing of biofuels and their possible effect on public attitudes towards different biofuels technologies and policies (Chang, 2009; Delshad and Raymond, 2013). That of Delshad and Raymond (2013) confirmed that public attitudes appear to be shaped by new media frames, especially among those who indicated a high degree of attention to the media. Other important factors that can influence public opinion on biofuel issues include regional economic interests, partisanship and ideology. An interesting question that emerged when preparing this literature review was that the public did not fail to embrace biofuels; rather, it is a matter of being uninformed about the alternative fuel. In the United Kingdom (UK), a print media analysis was made on the biofuel discourse for the period from 1995 to 2012 . The study found only a marginal role played by scientific actors in the debate, despite support for biofuels by the European Union policy and the German government.

While several studies have been carried out to assess public acceptance of perceptions on biofuels, the studies concentrated on public opinion or knowledge and consquently failed to connect those reasons to the specific type of biofuels (Delshad et al., 2010; Villamil, Alexander, Silvis and Gray, 2012)). Against this backdrop, the present seeks to understand the public's knowledge, attitudes and beliefs in South Africa's bio-based economy.

\section{Materials and methods used in the study}

Biofuels are being developed in a complex, dynamic and diverse context, so it is important to assess perceptions of the stakeholders. The study set out to answer the question: what is the level of knowledge, perceptions, attitudes of various stakeholders in relation to biofuels and use in South Africa? Twin objectives were laid out to respond to the research question: first, to understand knowledge, attitudes and perceptions of stakeholders on biofuels; and, second, to examine policies and institutions that were put in place to support biofuels in a bio- based economy. The study employed both quantitative and qualitative research methods. Saunders et al. (2012) have pointed out that, at every stage of research, assumptions that are made about human knowledge, and the nature of the realities encountered in the research inevitably shapes the understanding of the research questions, the methods used and interpretation of findings. The present study adopted the subjective philosophy. For Saunders et al., subjectivity asserts that social phenomena are created from the perceptions and consequent actions of social actors. This means that it is necessary to study the details of a situation to understand what is happening, or even the reality occurring behind what is happening. In this study, it was important that the survey instrument consisted of both 
close-ended items and looser items where the respondents could express their knowledge about biofuels and the perceptions in their own words. An instrument limited to Likert-type scale items was therefore inadequate.

Conducting a knowledge, attitude and perception survey is a substantial undertaking, requiring significant time, financial resources, personnel and logistics. The interview schedule consisted of various questions in three broad areas: general environment, awareness and concern. The interviews were recorded, transcribed, and analysed from a thematic analysis approach (Boyatzis, 1998). An email list with 300 contacts was sent with a Survey Monkey link between November 2014 and April 2015. The targeted stakeholders included regulatory agencies and government personnel, academia and research, industry professional, forest landowners, and general consumers. The response rate was lower than expected, with only 148 responses. Age, gender and education were used as control variables, where age was measured as a continuous variable and gender as a dichotomous variable with female-coded as 0 and male-coded as 1 . The reliability of the seven questions asked was tested by using the Cronbach's alpha, which showed a higher satisfactory level of internal consistency (alpha $=0.84$ ). A reliability coefficient of 0.70 and above is usually considered acceptable and desirable for consistency levels (Qin and Brown, 2007). The next section presents the key findings of the study.

Age often plays a critical role in terms of information targeted at specific market segments. Figure 2 shows the age of the 148 respondents, the majority of whom were between 35 and 54 years.

Figures 3 and 4 indicate the sex and level of education of respondents. Michael (2013) contended that females are typically more supportive of measures to protect the environment, thus it may be that women were likely to view the use of biofuels through the lens of environmental protection and as a superior alternative to fossil fuel.

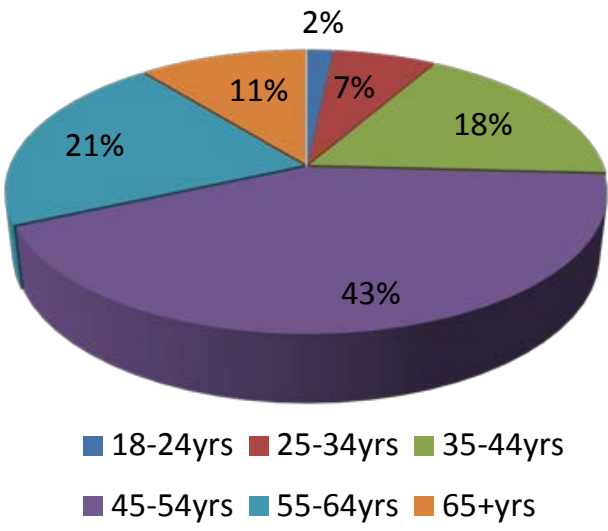

Figure 2: Characterisation of respondents $n=148$.

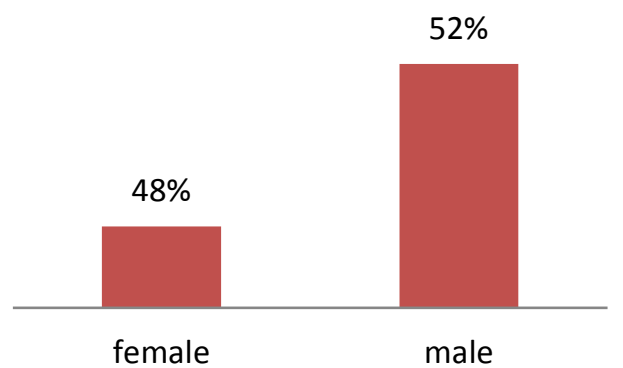

Figure 3: Sex of the respondents.

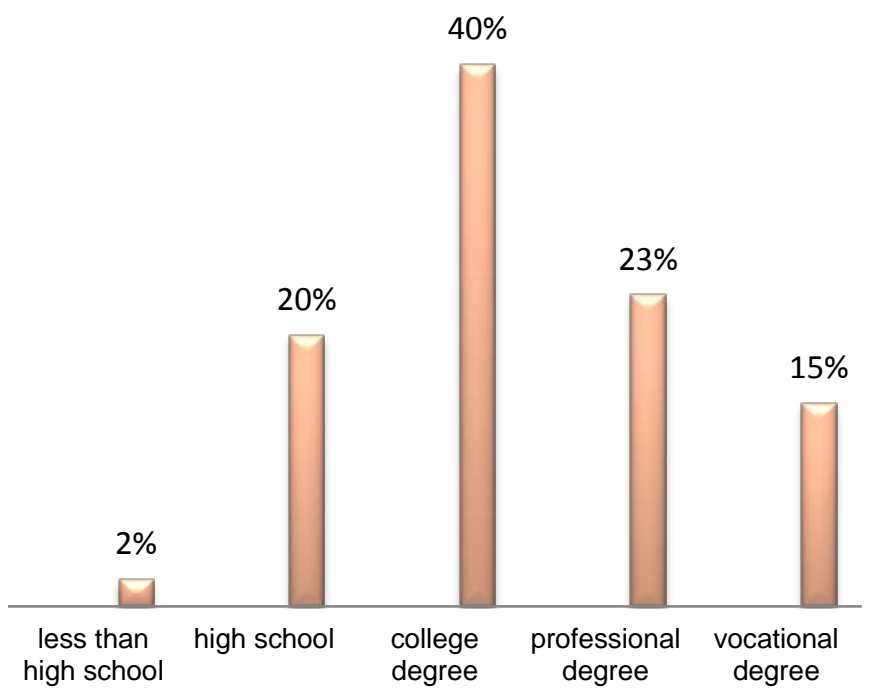

Figure 4: Level of education of the respondents.

\section{Results}

The point of departure for the study was to gauge the level of understanding of the term biofuel. Answers indicated a superficial understanding of biofuels. Most of the respondents said that biofuels is produced from crops. Further interrogation showed that sugar, maize and wheat were the bestknown crops.

The first question with regard to general environmental awareness was to ask the stakeholder's opinion as to the country's most pressing problem. Essential dynamics in attitudes towards biofuels can, subsequently, be inferred through the level of knowledge. The impending energy crisis or even the already existing energy crisis affecting generations includes problems of poverty, hunger and spread of deseases. It was therefore to solicit stakeholders perceptions on these matters, rather than making generalisations on what may be perceived as the country's general problem. Most of the stakeholders interviewed perceived hunger as the major problem, followed by poverty and inequality. Many respondents felt that the introduction of biofuels was secondary, except for those with enough knowledge who understand the energy crisis that warranted the country's active involvement. A follow up question 
was: 'In your opinion who do you think is responsible for tackling climate change in South Africa?' They were various responses to the question, summarised in Figure 5.

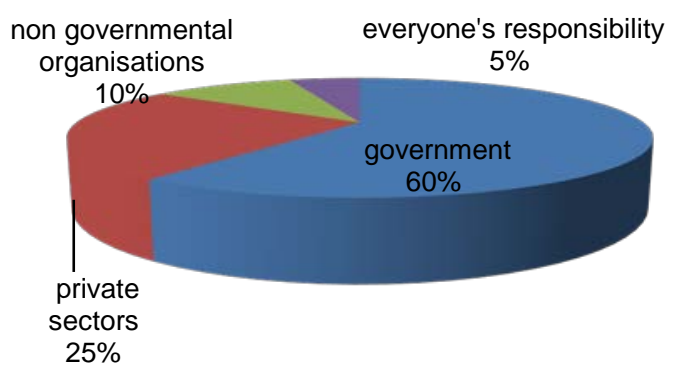
Figure 5: Summary of who is supposed to tackle
climate change.

The success and failure of biofuels is placed on the shoulder of the government: $60 \%$ of the respondents believed so, while $10 \%$ believed it is the responsibility of non-governmental organisation and $25 \%$ think that the private sector should take the responsibility. Many respondents, then, believe that it requires political buy in and commitment from the government. Figure 6 shows responses regarding perceptions as to whether biofuels are a solution to climate change.

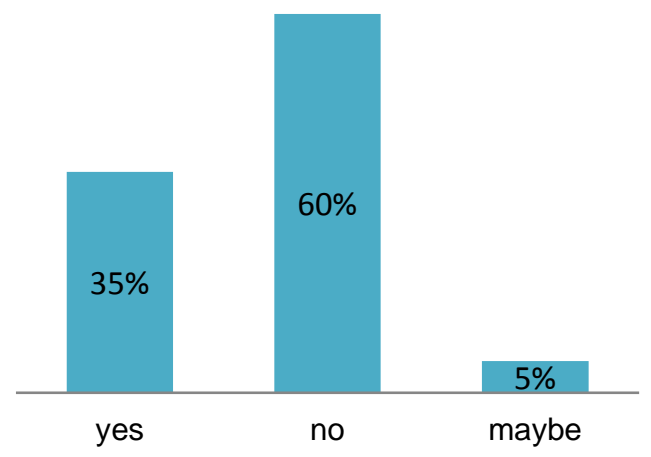

Figure 6: Biofuels as a solution to climate change/sustainable development.

The study also sought to find out how people relate to the prospect of using biofuels in a bio-based economy. To this end, respondents were asked which sources of biofuels they would be willing to purchase. The general feeling is that people are more comfortable with biofuels from sugar beets, algae, and crop waste - not compromising food availability. Figure 7 highlights some of the preferences of the biofuel technologies.

Using sugar beets proved a popular strategy, possibly because bio-ethanol has been used for some time now. Malawi and Zimbabwe have produced biofuels from sugarcane since 1982 despite associated difficulties, while the United States of America and Brazil also produce biofuels from sugar. Studies in America indicate increasing public acceptance of bio-ethanol (Biowatch Newsletter, 2010). Delshad et al. (2010) found that support for biofuels varies considerably according to the type of crop. There are unintended consequences of biofuel production and use, as was indicated by the results from the respondents. The majority pointed to the negative consequences of biofuel production and use; mainly on land use for production of biofuels crops and the effects on food supply and food prices locally and globally. Figure 8 reflects responses to the question regarding land availability in South Africa for biofuel production.

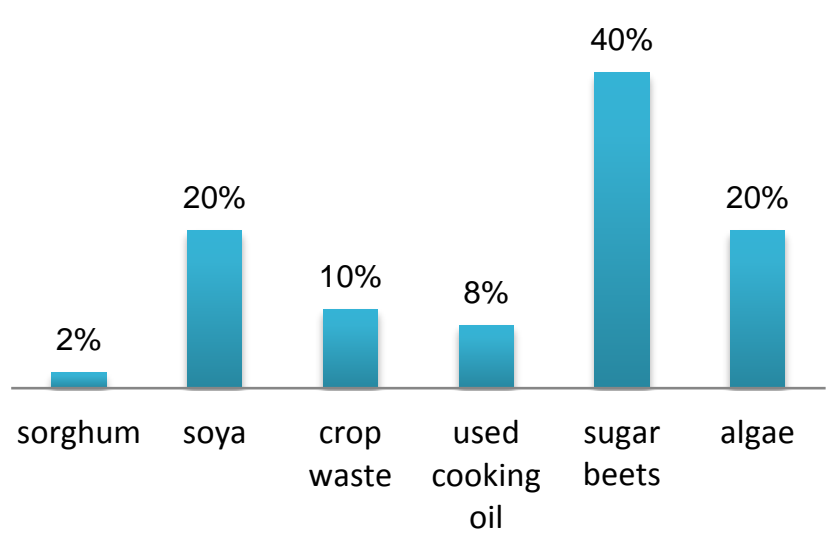

Figure 7: Determining willing to purchase biofuels.

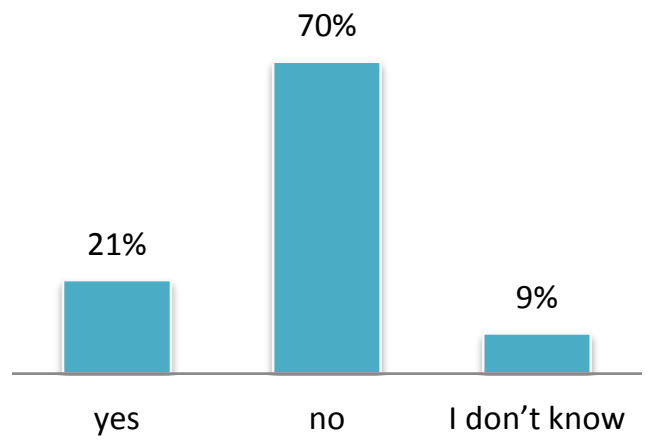
Figure 8: Determining land availability for
producing biofuels.

Figure 8 shows that $70 \%$ of the respondents said that South Africa does not have land for biodiesel production, whereas $21 \%$ believed that land is available. Internationally, the land issue has become a major matter of controversy (Bergsma et al., 2007; Cotula, 2008; Borras et al., 2012; HLPE, 2013). The introduction of biofuels is believed to have contributed to price increases in 2008 (Flammini, 2008; Johnson, 2008 and Schmidhuber, 2006). Chakravorty et al. (2015) carried out a study to determine the long-term impact of biofuel studies on food prices. The researchers used a partial equilibrium 
framework to show that demand-side effects in the form of population growth and income-driven preferences for meat and dairy products rather than cereals may play as much of a role in raising food prices as biofuels policy. The study established that, with differential land quality, there is a significant amount of new land that will be converted to farming and in the process causing a modest increase in food prices. Because of the contestations surrounding the use of first generation feedstock, additional research is being carried out on second and third feedstock generation (Hochman, 2011; Hertel, 2011 and IEA, 2013). The use of used cooking oil has gained prominence in South Africa, leading to many companies being established. Some of the extracts regarding availability of land for biofuel production are given in Table 2 .

Table 2: respondents' selected views on land availability.

\begin{tabular}{ccc}
\hline $\begin{array}{c}\text { Age } \\
\text { (years) }\end{array}$ & Views & $\begin{array}{c}\text { Yes/ } \\
\text { No }\end{array}$ \\
\hline 33 & $\begin{array}{c}\text { Area based projects and } \\
\text { community-based projects are } \\
\text { more sustainable }\end{array}$ & Yes \\
& No views & Yes \\
33 & $\begin{array}{c}\text {..but need for sustainable } \\
\text { practices that do not disempower } \\
\text { communities should be } \\
\text { emphasised }\end{array}$ & Yes \\
& em
\end{tabular}

The general feeling of the stakeholders was that biofuels were controversial and as such unattractive. Cai et al. (2011) and Larborde (2011) espoused that the major constraint on our ability to expand biofuel production to reduce our dependence on fossil fuels is likely the limited amount of land available for producing energy crops and for expanding refinery and transportation infrastructure. It remains a pressing issue and a borne of a contention as far as if the world has sufficient land available for biofuel crop cultivation that could be utilised without compromising the concerns of stakeholders. Figure 9 highlights respondent's perception on the significance of biofuels to the energy mix.

The majority of the respondents were of the view that biofuel would not make a meaningful contribution to the country's needs. The reason could be that biofuels as of now are not part of the energy mix and people have not been using them. The responses were based mainly on hearsay and what they hear through media.

The lack of awareness is not confined to South Africans. Michael (2012) observed a similar trend in the United States of America and Europe. He estab- lished that the public has not failed to embrace biofuels, but largely uninformed about them. Citizens rely on their ideological beliefs according to the knowledge deficit approach. As a result, certain subgroups can be highly susceptible to persuasive appeals by political elites. Halder et al. (2012) expressed that there is need for societal support especially among the young generation to cultivate a positive attitude.

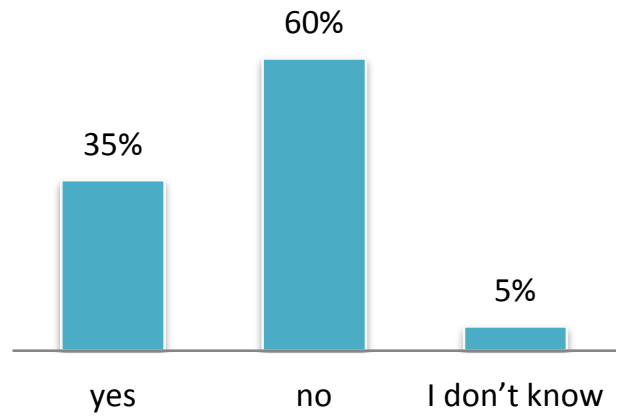

Figure 9: Determining significance of biofuels to the country's energy mix.

Another objective of the study was to establish whether stakeholders understand the policies and institutions meant to show government commitment to biofuel production; hence the following question was asked: Is there a high-level commitment by the state, private institutions to implement biofuels in the country? Two thirds of the respondents believe that there is high level commitment, while one-third do not think so. Further interrogation discovered that lack of knowledge of what are biofuels, and to name some of the institutions was a problem. Brent (2014) mentioned that, at a national level, some other policies and strategies exist in South Africa to support the production of biofuels and more continue to be developed. It is also important to note that new policies do not in themselves create an enabling environment for biofuels programme development and implementation. This requires a balanced mix of professional, technical, financial and legal service providers, innovative funding as well as interdepartmental leadership and project facilitations for success. Table 3 presents some of the views with regard to available institutions supporting biofuels production.

There is continued support by government for biofuel production as evidenced by the regulatory and the institutional framework despite some doubts about the suitability of biofuels. Many respondents showed understanding of the potential benefits and costs of increasing demand for biofuels. All stakeholders interviewed mentioned feedstock availability and price competitiveness as being the main obstacles. These barriers are closely related because 
the more feedstock available on the market, the less is the production cost. The ability to remain costcompetitive depends on other issues such as government incentives in the form of tax credits or support of biofuels producers in the form of grants. The other primary factor that affects the competitiveness of biofuels is the price of petroleum fuels. Recent years showed that global crude oil prices directly affect petroleum prices.

Table 3: Determining institutional support for biofuels production.

\begin{tabular}{cccc}
\hline Sex & Age (years & Yes/no & Views \\
\hline Male & 33 & N/A & Not sure \\
Male & 52 & Yes & Private sector \\
Male & 37 & Yes & Government is key \\
Female & 26 & Yes & $\begin{array}{c}\text { Government and private } \\
\text { sector is important }\end{array}$ \\
Female & 47 & Yes & $\begin{array}{c}\text { Public private partnership } \\
\text { is crucial }\end{array}$ \\
\hline
\end{tabular}

\section{Discussion}

The objective of the study was to understand the knowledge, attitudes and perceptions of stakeholders on biofuels. It was found that crops such as sugar, maize and wheat were the best known to the participants. Biofuels in South Africa are still at an early stage of practical exploitation and mostly involve first generation biofuels, and extensive research is underway on second and third generation biofuels. There were general positive responses regarding biofuels as an enabler in a bio-based economy, with most of the views agreeing on the necessity and significance of biofuels. The main concern, however, was the availability of land and the expertise to cultivate associated crops on a large scale. A general feeling was that the main obstacle to the acceptance of biofuels as an alternative form of energy is the fear of trying something new; hence, stakeholders were sceptical of using it in their engines. Biofuels, like any emerging technology, have the potential to cause ethical dilemmas by amplifying the opposing values of multiple stakeholders. Policy can, subsequently, be an instrument used to buffer these differences by seeking a balance between postulated positive and negative environmental and socioeconomic effects of biofuels expansion and associated developments of new feedstocks. This is a precarious endeavour at best. The biofuel community faces extreme ethical scrutiny to account for not only the direct effects of widespread adoption but the indirect effects as well. The interactions between stakeholders surrounding these controversies, in large part, will determine what role biofuels play in a range of issues including:

- South Africa's future energy portfolio;

- the strategies adopted to mitigate climate change;

- changes in agriculture, including the types of feedstock's used and how these feedstocks are grown; and

- how to best manage the increasing demands of humans on resources and the environment. The acceptance of biofuels feedstock as 'renewable' or 'sustainable' epitomises the myriad ethical issues accompanying biofuels expansion.

The study generated much interest among the respondents with most of them expressing the feeling that biofuels are a business opportunity. This was substantiated by government's commitment to intensify biofuel production in November 2012 and February 2013 through the Department of Environmental Affairs, when it set aside R800 million to establish the Green Fund (Green Fund Annual report, 2012 /2013). This allocation represents the initial resources available for disbursement by the Green Fund. The major objective of the fund is to support green initiatives to assist South Africa's transition to a low-carbon, resource-efficient and climate-resilient development path, and delivering high impact economic, environmental and social benefits. The Green Energy Efficiency Fund supports the introduction of energy efficiency and self-use renewable energy technologies and will ultimately continue contributing to global climate protection, while supporting South Africa's economic development and growth. Investments are encouraged in energy efficiency and renewable energy projects aimed at improving energy efficiency to facilitate South Africa's transition towards a low-carbon economy. The energy and related cost savings will drive improved production capacity, operational effectiveness and competitiveness resulting in job creation. The country, since then, has witnessed companies producing biodiesel production using used cooking oil (e.g. Matayo Biofuels Company). Strategies and financial assistance, as far as government support is concerned, were put in place to emphasise a positive attitude towards biofuels as an enabler in a biobased economy. Efficiency considerations continue to indicate that feedstock and biofuel production can be done most favourably in developing countries, where the environment tend to promote biofuel production at a low cost. Energy security considerations, however, have prompted less efficient countries to engage in biofuel production irrespective of economic and environmental considerations (UNCTAD, 2014; OECD, 2008). 


\section{Conclusions}

The link between climate change and the bio-based economy has taken the concept of producing fuel from biomass into public debate. The present study aimed to explore and gauge the knowledge, attitudes and perceptions of stakeholders regarding biofuels. It was beyond the scope of this study to suggest specific and economic decisions concerning biofuels. The majority of the respondents expressed doubt about the suitability of biofuels and the availability of land for biofuels production. The study also established that there is seemingly government and institutional commitment, though the use of biofuels in the country is not yet mandatory. Optimism and political commitment concerning the use of biofuels as an enabler have been expressed by the government, particularly in the unveiling of the biofuels industrial strategy and the Green Fund that ushered in new business opportunities, creation of jobs, and offering mitigation of climate change. The study illustrates the complexity of understanding and managing environmental and climate-change issues in the contemporary world. The enactment of policies, strategies and the establishment of funding mechanisms may contribute to the growth of the biofuels industry, as well as to the development of the corresponding industry of equipment production and services, leading to the deployment of a new technological regime. Scepticism amongst stakeholders about the ability of biofuels has, nonetheless, been the major obstacle. There is, therefore, a need for government to engage and educate the citizen on the benefits of using biofuels by, for example, including it the education curriculum. The main conclusion of the study is that proper government support, together with favourable macroeconomic conditions, could influence the success of biofuels in a bio-based economy. This requires enough consideration to ensure correct formulation of strategies for the development of such an industry, together with the impact of macroeconomic conditions on their successful implementation.

\section{References}

Amigun, B., Musango, J, K., Stafford, W. 2011. Biofuels and sustainability in Africa. Renewable and Sustainable Energy Reviews (15): 1360-1372.

Avinash, A, Subramaniam, D. and Murugesan. A. 2014. Bio-diesel: global scenario.

Bergsma, G., Kampman, B., Croezen, H. and Sevenster, M. 2007. Biofuels and their global influence on land availability for agriculture and nature: A first evaluation and a proposal for further fact finding. Delft, CE. Available online at: www.cedelft.eu/?go $=$ home. downloadPub\&id=505\&file=07_8323_03.pdf [Accessed 20 September 2016].
Bhaskar, R. 1978. A realist theory of science. London. Available online at: uberty.org/wp-content/uploads/.../Roy_Bhaskar_A_Realist_Theory_of_Science.pdf [Accessed 20 July 2016].

Biochem Quarterly Newsletter. 2010. New faces of the economy: Bio-based products spur green job growth. Biotech Now. (09/06/2010) Available online at: http://www.biochem-project.eu/download/innova/newsletter/qn/BIOCHEM\%20quarterly\%20Newsletter\%2001\%20-\%20September\%202010.pdf [Accessed 20 July 2016].

Bioethanol for Sustainable Transport. 2009. Report on survey of fleet operators attitudes towards ethanol vehicles and fuel. London. No 9.25. Available online at: www.stockholm.se/Global/.../best/reports/ D9.25_FleetSurvey_Imperial_090331.pdf [Accessed 20 August 2015].

Borras Jr., S.M. 2012. Land grabbing in Latin America and the Caribbean. Journal of Peasant Studies, 39(3-4): 845-872.

Brent, A. 2014. The agricultural sector as a biofuels producer in South Africa. Understanding the food energy water nexus. Understanding the food energy water nexus. WWF-SA, South Africa. WWF Report . Available online at: /biofuels\%20in\%20south\%20africa/6_a16270_the_agricultural_sector_as_a_biofuels_producer_in_sa_online.pdf. [Accessed 20 August 2015].

Brown, C.E, Kim, S.C, Stichler, J.F and Fields, W. 2010. Predictors of knowledge, attitudes, use and future use of evidence-based practice among baccalaureate nursing students at universities. Nurse Education Today 30(6): 521-527.

Cacciatore, M.A., Binder, A.R., Scheufele, D.A and Shaw, B.R. 2012. Public attitudes towards biofuels. Effects of knowledge, political partisanship and media use. Politics and the Life Sciences. 31(1-2): 3651.

Cai, X., Zhang, X. Wang. D. 2011. Land availability for biofuel production. Environmental Science \& Technology 45(1): 334-339. Available online at: http://pubs.acs.org/doi/pdf/10.1021/es103338e [Accessed 20 May 2016].

Chakravorty, U., Hubert, M., Moreaux, M and Nøstbakken.L. 2015. The long-run impact of biofuels on food prices. Discussion paper. Resources for the future. Washington. Available at: http://www.rff.org/ files/document/file/RFF-DP-15-48.pdf [Accessed 16 February 2016].

Chang, S. 2009. The influence of media frames on the public's perception of biofuels. Graduate Theses and Dissertations. Paper 10593.

Clarkson, M.B.E. 1995. A stakeholder framework for analysing and evaluating corporate social performance. Academy of Management Journal 20(1): 92-118.

Clever Consult BVBA. 2010. The knowledge-based bioeconomy (kbbe in Europe: achievements and challenges. Available online at: http://www.mercadosbiotecnologicos.com/documents/the_knowledge based_bioeconomy_kbbe_in_europe.pdf [Accessed 16 March 2016]. 
Cotula, L., Dyer, N. and Vermeulen, S. 2008. Fueling exclusion? The biofuels boom and poor people's access to land. Rome, FAO and London, IIED.

Delshad, A and Raymond, L. 2013. Media framing and public attitudes toward biofuels. Review of Policy Research 30(2).

Delshad, A.B., Raymond. L., Sawicki. V and Wegner, D.T. 2010. Public attitudes towards political and technological options for biofuels. Energy Policy 38: 3434-3425.

Department of Environmental Affairs [DEA]. 2012. Annual Green Fund report 2012/2013. Available online at: http://www.sagreenfund.org.za/wordpress/wp-content/uploads/2014/12/Green_Fund_Annual_Report.pdf [Accessed 16 June 2016].

Department of Minerals and Energy [DME]. 2007. The biofuel industry: The strategy of the Republic of South Africa. Pretoria. Available online at: http:// www.energy.gov.za/files/esources/petroleum/biofuels_indus_strat.pdf\%282\% 29.pdf); 2007 [Accessed 6 September 2015].

Dwivedi, P., Alavalapati J. R. R. 2009. Stakeholders' perceptions of forest biomass-based bioenergy development in the southern US. Energy Policy 37(5): 1999-2007.

Flammini, A. 2008. Biofuels and the underlying causes of high food prices. FAO, Rome. Available online at: http://www.globalbioenergy.org/fileadmin/user_upload/gbep/docs/BIOENERGY_INFO/0810_Flammini_-_Biofuels_and the underlying_causes_of_high_food_prices_GBEP-FAO.pdf. [Accessed 17 January 2016].

Freeman, R.E 1999. Response: Divergent stakeholder theory, Academy of Management Review. 24(2): 233-236.

Freeman, R.E. 1984. Strategic management: A Stakeholder Approach. Pitman. Boston.

Funke, T.B. 2010. Biofuel production in South Africa: the games, the cost of production and policy options. Doctoral thesis, Faculty of Economic and Management Sciences. University of Pretoria, South Africa.

Funke, T.B., Strauss, P.G. and Meyer, F. 2009. Modelling the impacts of the industrial biofuels strategy on the South African agricultural and biofuels subsectors. Agrekon, 48 (3): 223-244.

Halder, P., Pietarinen., J. SariHavu-Nuutinen, B. and Pelkonen, P. 2010. Young citizens' knowledge and perceptions of bioenergy and future policy implications. Energy Policy 38 3058-3066.

Halder, P., Prokop. P., Chang, C., Usak, M., Pietarinen. J., Have-Nuutinen, S., Pelkonen. P and Cakir, M. 2012. International survey of bioenergy knowledge, perceptions and attitudes among young citizens. Bioenergy Research 5: 247-261. Available online at: www.http://dx.doi.org/10.1016/j.enpol.2011.01.009 [Accessed 17 January 2016].

Hertel, T.E. 2011. The global supply and demand for land in 2050: A perfect storm in the making? American Journal of Agricultural Economics, 93(2): 259275.
High Level Panel of Experts [HLPE]. 2013. Biofuels and food security. A report by the high level panel of experts on food security and nutrition of the committee on world food security. Rome.

Hochman, G., Rajagopal, D. and Zilberman, D. 2011. The effect of biofuels on the international oil market. Applied Economic Perspectives and Policy 33: 402427.

International Energy Agency [IEA]. 2012a. World Energy Outlook 2012, Paris: OECD/IEA.

International Energy Agency [IEA]. 2012b. $\mathrm{CO}_{2}$ Emissions from fuel combustion. Edition 2012, Paris: OECD/IEA.

International Energy Agency [IEA]. 2013. Cellulosic biofuels begin to flow but in lower volumes than foreseen by statutory targets. Available online at http://www.eia.gov/todayinenergy/detail.cfm?id=10131 [Accessed 15 August 2015].

Jensen, M. and Andersen, A.H. 2013 Biofuels: A contested response to climate change. Sustainability: Science, Practice, and Policy 9(1): 42-56.

Johnson, S. 2008. Commodity prices: Outlook \& risks. International Monetary Fund. Washington DC.

Jumbe, C.B.L., Msiska. F.B.M and Madjera. M. 2009. Biofuels development in Sub Saharan Africa: Are the policies conducive? Energy Policy 37: 4980-4986.

Laborde, D. 2011. Assessing the land use change consequences of European biofuel policies: Final report. IFPRI. Available online at: http://trade.ec. europa.eu/doclib/docs/2011/october/tradoc_148289.pdf. [Accessed 15 August 2016].

Morrone, M., Ben, J., Stuart, I. M. and Buckley, G. L. 2009. The challenges of biofuels from the perspective of small-scale producers in Ohio. Energy Policy 37: 522-530.

National Planning Commission - NPC. 2011. National Development Plan. National Treasury. Pretoria. Available online at: http://www.gov.za/sites/ www.gov.za/files/devplan_2.pdf [Accessed 15 August 2015].

Nhamo, G., Shava,S and Togo, M. 2011. The green economy and sustainable development. In Nhamo. G. (ed) Towards a common understanding in green economy and climate mitigation. AISA.

Oltra, C. 2011. Stakeholder perceptions of biofuels from microalgae. Energy Policy 39: 1774-1781.

Organization for Economic Cooperation and Development [OECD]. 2008. Biofuels support policies: An economic assessment. Paris: OECD.

Pradhan, A. and Mbohwa, C. 2014. Development of biofuels in South Africa: Challenges and opportunities. Renewable and Sustainable Energy Reviews (39): 1089-1100.

Prokop, P., Prokop, M. and Tunnicliffe, S. D. 2007. Is biology boring? Student attitudes toward biology. Journal of Biological Education 42 (1) 36-39.

Qin, J. and Brown. C. E. 2007. Public reactions to information about genetically engineered foods: Effects of information formats and male/female difference. Public Understanding of Science, 16 (4) (2007), 471-488. 
Rohracher, H., Bogner, T., Späth, P. and Faber, F. 2004. Improving the public perception of bioenergy in the EU. Final report to the European Commission. Available online at: http://ec.europa.eu/energy/ res/sectors/doc/bioenergy/bioenergy_perception.pdf. [Accessed 15 June 2015].

Saunders, M. N. K., Lewis, P. and Thornhill, A. 2012. Research methods for business students 6th edition. Harlow, England: Pearson Education.

Schmidhuber, J. 2006. Biofuels: An emerging threat to Europe's food security? Impact of an increased biomass use on agricultural markets, prices and food security: A longer-term perspective. FAO, Rome. Available online at: http://www.institutdelors.eu/ media/policypaper-schmidhuber-en.pdf?pdf $=$ ok [Accessed 15 August 2016].

United Nations Conference on Trade and Development [UNCTAD]. 2014. The state of biofuels market: Regulatory, commerce and development perspectives. UNCTAD/DITC/TED/2013/8.

Upham, P., Thornley, P., Tomei, J. and Boucher, P. 2009. Substitutable biodiesel feedstocks for the UK: a review of sustainability issues with reference to the UK RTFO. Journal of Cleaner Production. (17) S37S45.

US Energy Information Administration. 2013. International Energy Outlook. Washington. Available online at: http://www.eia.gov/outlooks/ ieo/pdf/0484(2013). pdf [Accessed 15 August 2016].

Villamil, M.B., Alexander, M., Silvis, H.A. and Gray, M. 2012. Producer perceptions and information needs regarding their adoption of bioenergy crops. Renewable and Sustainable Energy Reviews (16) 3604-3612.

Wesseler, J. and Zilberman, D. (Eds). 2016. The contribution of the emerging bio-economy to sustainable development. Springer. New York. 